\title{
Influence of the Traction Force and the Speed of Movement on the Strength Characteristics of the Locomotive Axles
}

\author{
Vasko Nikolov ${ }^{1 *}$ \\ ${ }^{1}$ Department Transport Equipment, Todor Kableshkov Transport University, Sofia, Bulgaria
}

\begin{abstract}
The article presents the dependencies obtained when researching the load on the locomotive axles, depending on the traction force and the speed of movement of the locomotive. The traction characteristic of the locomotive is the relationship between the traction force achieved by the traction motors and the speed of movement, and it is different under different driving conditions. Different modes of operation of locomotive axles are considered. A simulation of the axles' be haviour has been developed. The strength and deformation characteristics of the locomotive axles under different loading modes are calculated. A comparative analysis of the strength characteristics of locomotives with different classes of transmission mechanisms has been made.
\end{abstract}

Keywords: locomotive axles, strength characteristic, comparative analysis, traction characteristic, strength analysis, simulation, traction force

\section{INTRODUCTION}

Locomotive axles are subjected to heavy and variable loads during their operation. As a result, they accumulate fatigue of the material, leading to unacceptable failures in them. These failures are unacceptable because locomotive axles have a direct impact on the safety of trains and rail transport in general. The change in the load of the locomotive axles depends mainly on the magnitude of the torque with which they are loaded during the realization of the traction forces of the locomotive. Since the traction force is not constant, the load on them is variable. The traction force of a locomotive is a function of the current in the traction motors and the gear ratio of its axle gearbox and varies for the different power transmitted by the locomotive at different speeds. The present study aims to determine specific quantitative values of the strength characteristics of the locomotive axles depending on the traction force realized by the locomotive and its speed.

In the study, electric locomotives with individual drive of the axles with the help of a traction motor and a single-speed gear of the transmission mechanism were observed.

\section{TRACTION FORCE AND TRACTION CHARACTERISTICS OF LOCOMOTIVES}

The movement of trains on the track is considered to be translational, i.e., as if all its points have the same velocities in both direction and magnitude. In other words, the train is seen as a material point. The accepted assumption does not affect in any way the results of the train running calculations.

The study used the data and designs of the transmission mechanisms of several series of locomotives used in railway transport in Bulgaria: type of 43, 44, 45, which have the same design parameters of the transmission mechanism, types of 46 and 86 .
The first two types of locomotives (43-45 and 46) are constructed with transmission mechanisms - support-

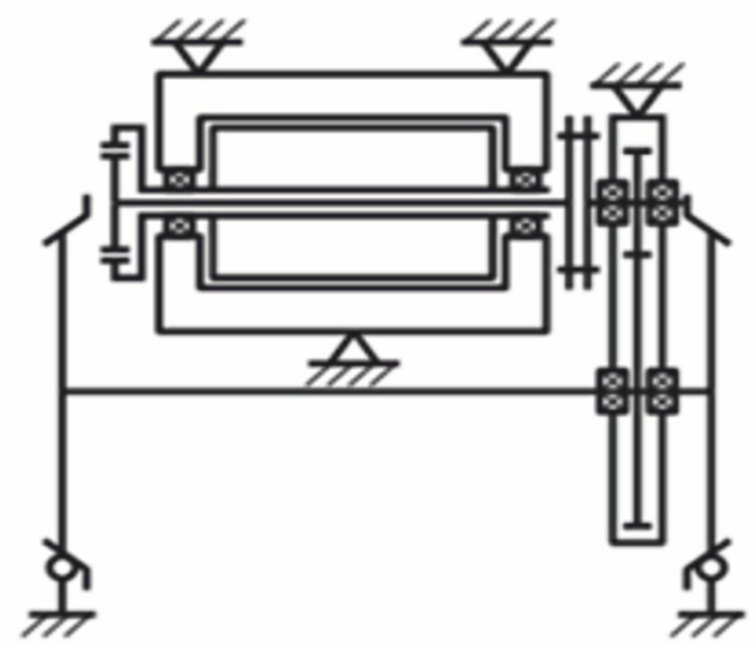

Figure 1

frame suspended traction motor and support-axle suspended wheel axle reducer (Fig. 1). In the considered locomotives the transmission of the torque is carried out by means of a cardan shaft, placed in the hollow shaft of the traction motor, as in locomotives 43,44 and 45 this is carried out by a cardan shaft and hinged connections at both ends, and in locomotives 46 - with using a shaft with gear clutches at both ends.

Locomotives of type of 86 have a transmission mechanism of the third kind - support-frame suspended traction motor and wheel axle reducer and one-sided transmission of torque with a hollow shaft placed on the axis of the wheel axle (Fig. 2). The transmission of the torque from the traction motor to the motor wheel is carried out by means of a gear, as the big gear is attached to the hollow shaft by means of elastic (rubber-metal) joints. In turn, the hollow shaft mounted on the drive

\footnotetext{
* Corresponding authors: Todor Kableshkov Transport University, Geo Milev str, va_r_nikolov@abv.bg

* Article presented at the conference in the oral form, HM2021, Vrnjačka Banja
} 
wheel is connected to one of the wheels in the same way by means of an elastic connection.

All this leads to a different distribution of the load on the motor wheel, as well as a different distribution of forces along it.

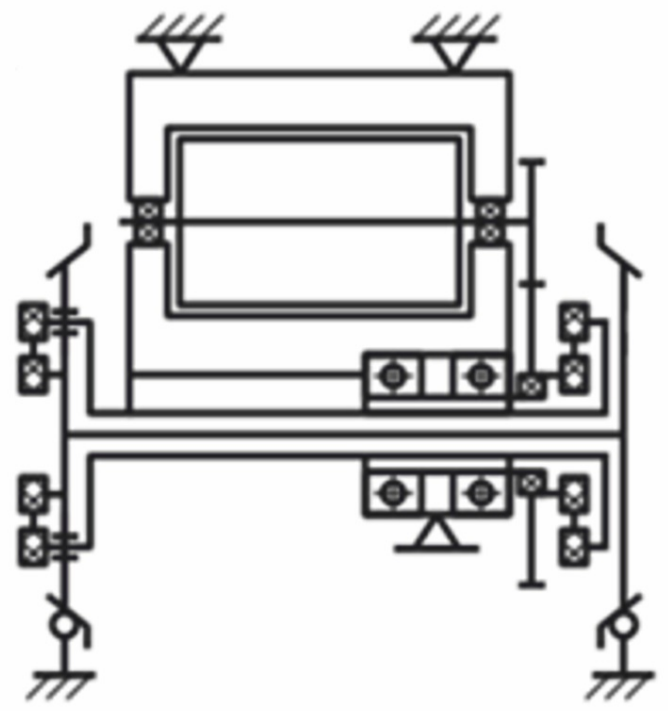

Figure 2

The formation of the traction force in the considered types of locomotives (with individual drive of the axles by traction electric motors) is carried out by the following mechanism:

When the current enters the traction motor of its armature, a torque $\mathrm{M}_{1}$ occurs, which is then transmitted to the locomotive of the locomotive by means of the gear. The moment $M_{1}$ can also be represented as a pair of forces, one of which $Z_{1}$ is applied at the point of contact of the teeth of the gears, and the other $Z_{2}$ is applied in the centre of the engine (Fig. 3 ). Therefore,

From where:

$$
M_{1}=Z_{1} r_{1}
$$

$$
Z_{1}=\frac{M_{1}}{r_{1}}
$$

But the force $Z_{1}$, acting on the large gear, generates torque:

$$
M_{2}=Z_{1} r_{2} \eta_{z}
$$

Substituting the force $Z_{1}$ with its value, we obtain:

$$
M_{2}=\frac{M_{1} r_{2}}{r_{1}} \eta_{z}
$$

In the above dependencies:

$M_{1}$ - torque created by the traction motor armature;

$\mathrm{M}_{2}$ - torque acting on the large gear;

$Z_{1}$ - force applied at the point of contact of the two gears;

$\mathrm{Z}_{2}$ - force applied in the centre of the rotor of the traction motor;

$r_{1}$ - radius of the small gear pressed on the shaft of the traction motor;

$r_{2}$ - radius of the large gear pressed on the axis of the motor wheel;

1 - length of the arm from the centre of the rotor of the traction engine to its jet support;
$\mathrm{R}$ - radius of the wheel of the motor wheel on its rolling surface;

$A_{1}$ - point of contact of the teeth of the gears;

$A_{2}$ - centre of rotation of the rotor of the traction motor;

$\mathrm{A}_{3}$ - centre of rotation of the motor wheel;

$\mathrm{A}_{4}$ - point of suspension of the reaction;

$\mathrm{P}$ - part of the weight of the locomotive, falling on the respective motor wheel (axle load);

$\mathrm{V}$ - direction of movement of the crew.

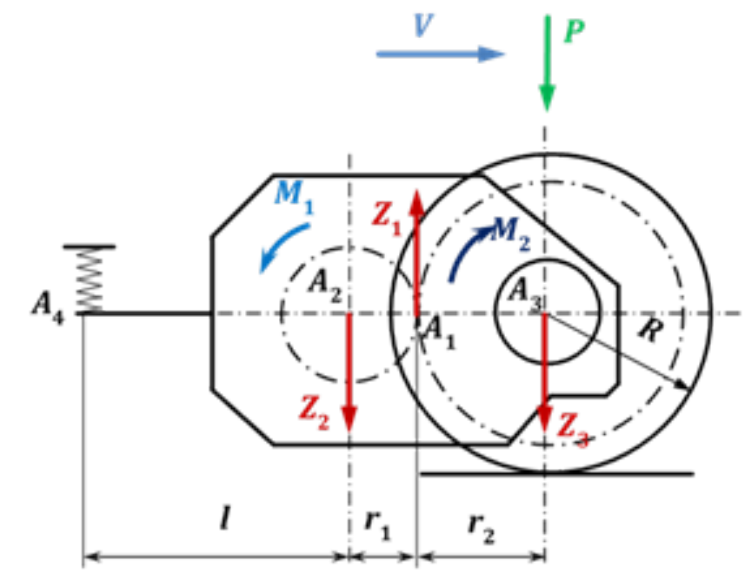

Figure 3

The proposed considerations apply to locomotives with second-class transmission mechanisms. With small additions to the above dependencies, they can also be adapted for locomotives with third-generation gears.

The traction characteristic of the locomotive is a graphical relationship between the tangential traction force $F_{k}$ and the speed of the train $\mathrm{V}$ at different modes of operation of the locomotive power system and with in the limits of reliability, stability, and safety.

To assess the impact of the torque created on the drive wheel in order to realize the traction force of the locomotive, it is necessary to take in to account both the values of traction force and the speed at which they are realized, i.e., to analyze the traction characteristics of each type of locomotive in order to calculate the load on the motor axles at each operating mode.

\section{WHEELSET LOAD}

The forces to be taken into account in the design calculations of the axle shall be determined so as to represent a constant fatigue load applied over the entire service life of the element, which is equivalent to the full sum of the various loads occurring during operation (Fig. $3)$. caused by:

The forces acting on the locomotive axles are

- The mass of the locomotive:

o $\mathrm{Q}_{1}$ and $\mathrm{Q}_{2}$ - vertical forces applied in the axle necks arising from the mass of the locomotive together with the mass of the bogies in which the respective axles are located, $\mathrm{N}$;

o $Z_{1}$ and $Z_{2}$ - vertical reactions occurring at the contact points between the wheels and the rails due to the mass of the locomotive, $\mathrm{N}$; 
$\mathrm{Y}_{1}$ and $\mathrm{Y}_{2}$ - horizontal reactions occurring at the contact points between the wheels and the rails due to the movement of the locomotive in a curve, $\mathrm{N}$;

$F_{i}$ - force generated by the unsprung masses pressed on the axis between the necks. This force exists only in locomotives whose transmission mechanisms are of the second kind with axially suspended axle gearboxes. In this case these are locomotives $43,44,45$ and locomotives 46 , $\mathrm{N}$;

$\mathrm{F}^{\prime}{ }_{\mathrm{iz}}$ - vertical component of the traction force realized by the locomotive. This force exists only in locomotives whose transmission mechanisms are of the second kind with axially suspended axle gearboxes. In this case these are locomotives $43,44,45$ and locomotives 46 , $\mathrm{N}$;

The braking process - in the present study these forces will not be considered;

The traction forces that the locomotive realizes:

$X_{1}^{\prime}$ and $X_{2}^{\prime}$ - horizontal reactions arising from the traction forces and applied at the points of bearing of the axle with the axles, N;

$Z_{1}^{\prime}$ and $Z_{2}^{\prime}$ - vertical reactions arising from the traction forces and applied at the points of bearing of the axle with the axles, N;

$F_{i z}^{\prime}$ - vertical component of the force $F_{i}^{\prime}$, generated by the torque of the traction motor, N;

In addition to the listed forces, the main role in the load of the locomotive wheel is played by the torque generated by the current in the traction motor, which is the primary reason for creating the traction forces realized by the locomotive. In the case of second gears (locomotives $43,44,45$ and 46) this is done with the help of the axle mounted on the axle (Figs. 4 and 5), and in the case of locomotives with third gear (locomotive 86 ) - by means of a hollow shaft mounted on the axle of the axle, which is an intermediate element between the large gear and one of the driving wheels of the axle, connected to each other by elastic metal-rubber elements (Fig. 6).

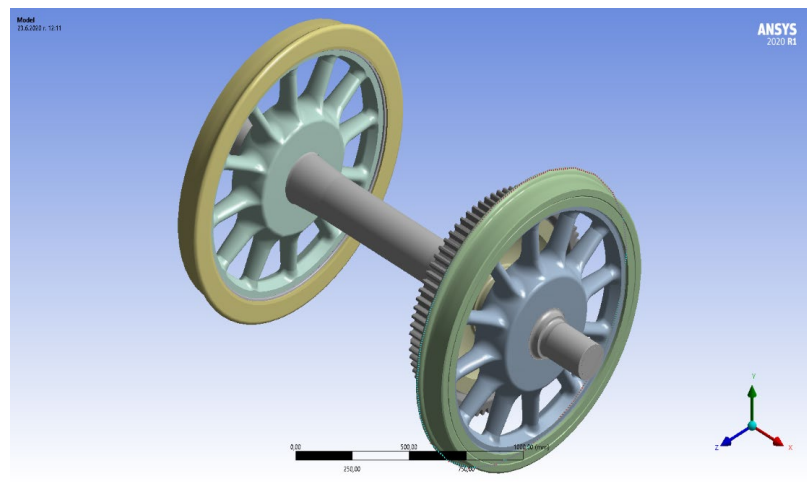

Figure 4

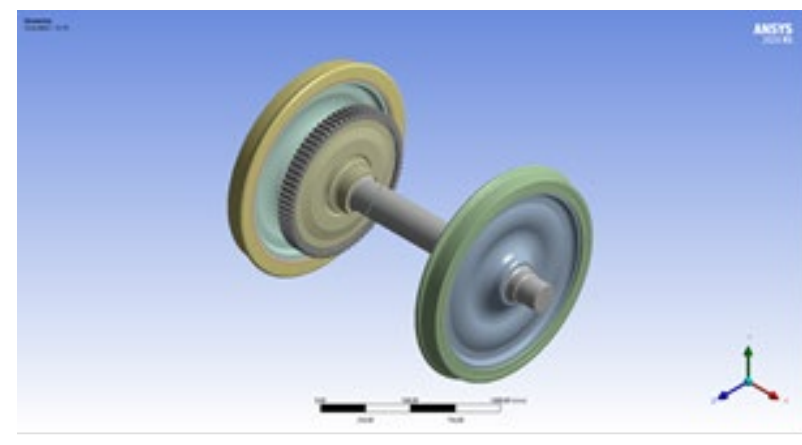

Figure 5

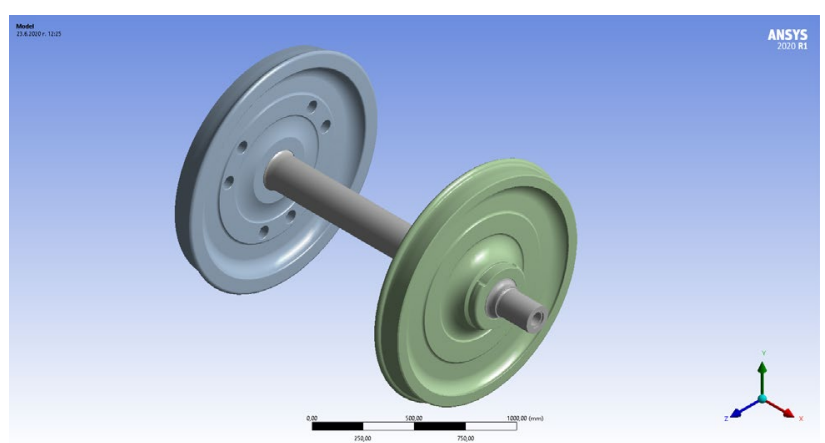

Figure 6

\section{MODELING AND STRENGTH ANALYSIS OF THE WHEELSETS}

The strength analysis of the wheelsets was performed using the finite element method (FEM).

For the successful analysis of the considered nodes the accuracy of the chosen model is of special importance. It should be as close as possible to the actual design, while being simple enough and not complicating the calculations unnecessarily. The loads in the selected model must also correspond as much as possible to the actual ones in terms of size, location and direction, and the selected supports must sufficiently provide the necessary degrees of freedom of the considered elements.

The three-dimensional model of the axles of the various locomotives is made with the help of a computer program and is integrated into the software product ANSYS Workbench, with the help of which the strengthstrain analysis is made.

In the analysis, the results for the following parameters were examined:

- Equivalent stress;

- Equivalent elastic strain;

- Total deformation;

- Safety factor under static load;

- Fatigue tool safety factor;

- Fatigue tool, Life;

\section{RESULTS OF THE CONDUCTED SIMULATIONS}

The simulations were performed at a certain speed (respectively, rotation at a certain angular speed), varying from rest at the moment of departure $(0 \mathrm{~km} / \mathrm{h})$ to the design speed at the maximum torque corresponding to the set speed according to the traction power of the locomotive in question. 


\subsection{Wheelsets of locomotives 43-45}

\subsubsection{Equivalent stress acting on the wheelset.}

In fig. 7 shows the results obtained during the simulation for the equivalent stress acting in the axle of locomotives 43-45, and two graphs are formed: for the maximum effective stress obtained in the holker (the transition between the two subhead parts - the wheel and the gear - fig. 8) and for the average for the axle stress in the whole range of speeds. The maximum stress takes values from $108.43 \mathrm{MPa}$ at start-up to $103.43 \mathrm{MPa}$ at maximum speed and decreases by $4.83 \%$. The tendency of the values of the maximum stress is towards continuous decrease. At the average value of the stress acting on the wheel, the maximum value initially assumes a value of $3.92 \mathrm{MPa}$, with an increase in speed there is a slight tendency to decrease to $3.78 \mathrm{MPa}$ at $30 \mathrm{~km} / \mathrm{h}$. This trend intensifies and the minimum value reaches the average equivalent stress at $70 \mathrm{~km} / \mathrm{h}-3.35 \mathrm{MPa}$, after which the values begin to increase and the highest value of 5.195 MPa it reaches at a maximum speed $-130 \mathrm{~km} / \mathrm{h}$. The average equivalent stress between 0 and $30 \mathrm{~km} / \mathrm{h}$ tends to decrease by $3.8 \%$ (between 3.92 and $3.78 \mathrm{MPa}$ ), and between its minimum value at $70(3.35 \mathrm{MPa})$ and the maximum at $130 \mathrm{~km} / \mathrm{h}(5,195 \mathrm{MPa})$ increased by $35.5 \%$.

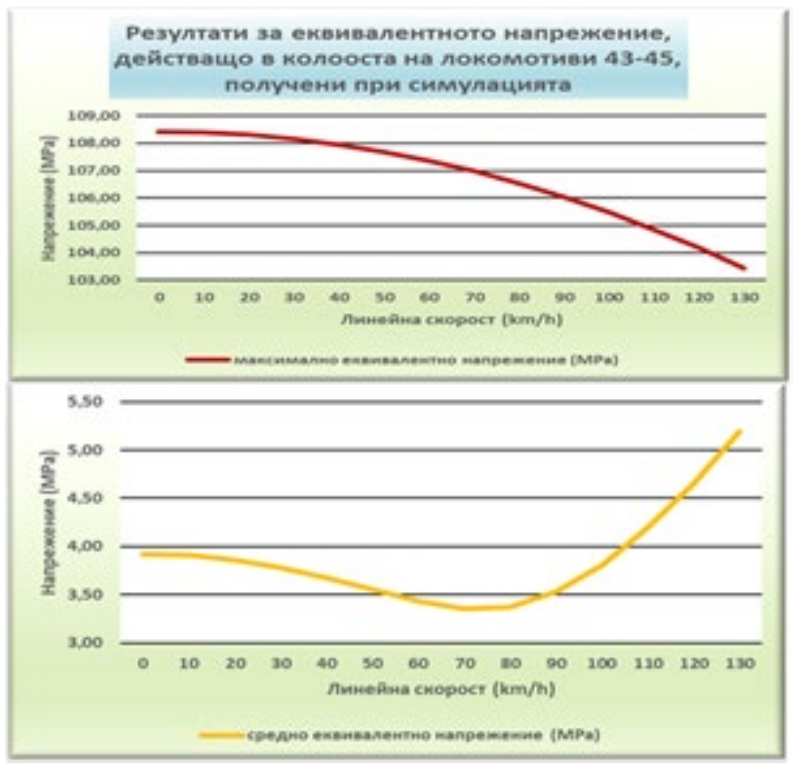

Figure 7

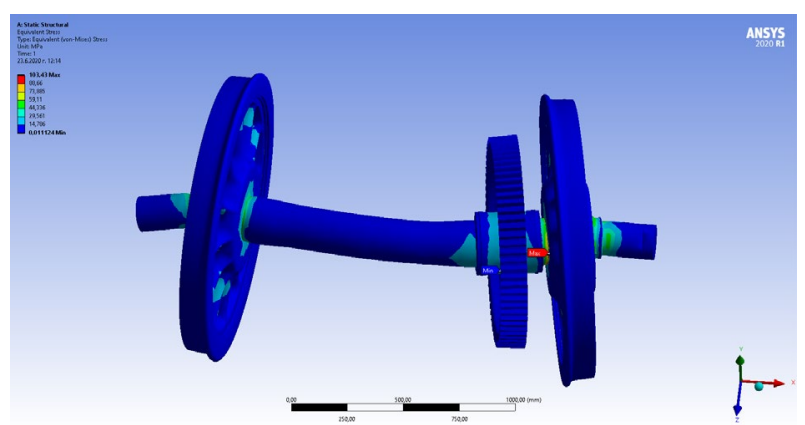

Figure 8

\subsubsection{Equivalent elastic strain}

The maximum value of the equivalent elastic strain of the wheel is observed in the holker and decreases with increasing speed, the decrease being $4.82 \%$ (Fig. 9).

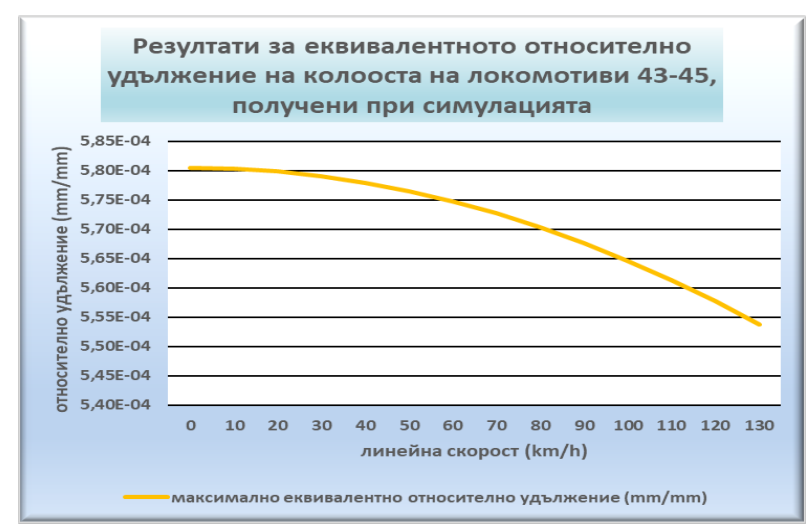

Figure 9

\subsubsection{Total deformation}

The total deformation of the wheelset illustrates its deformation under load in operating conditions from rest to movement at the maximum allowable speed for the locomotive (Fig. 10). The change in deformation along the wheel itself under different operating conditions increas es from $0.206 \mathrm{~mm}$ when starting to $0.219 \mathrm{~mm}$ at a maximu speed in the range of $5.95 \%$.

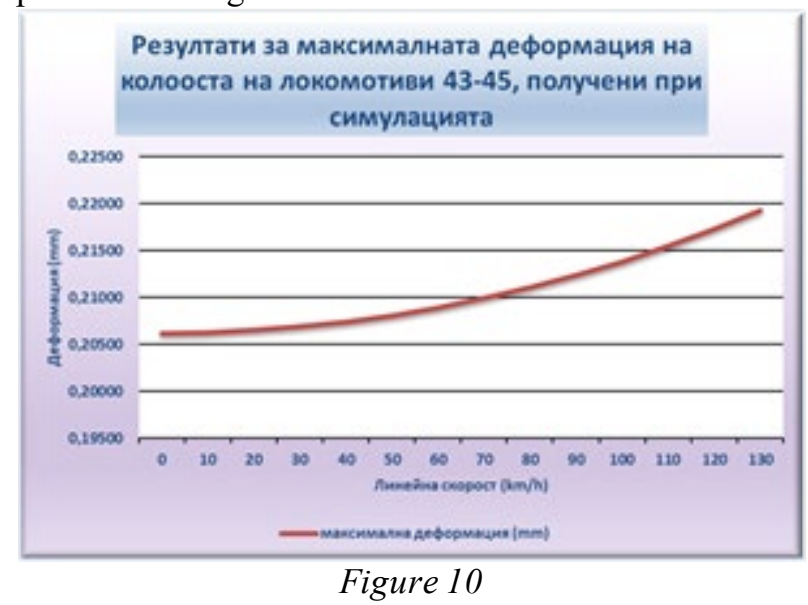

\subsubsection{Safety factor under static load}

The distribution of this indicator in the different operating modes is shown in fig. 11 . The trend is towards continuous growth. Its values increase from 2.3 at the time of departure to 2.717 at maximum speed, i.e., with $4.6 \%$.

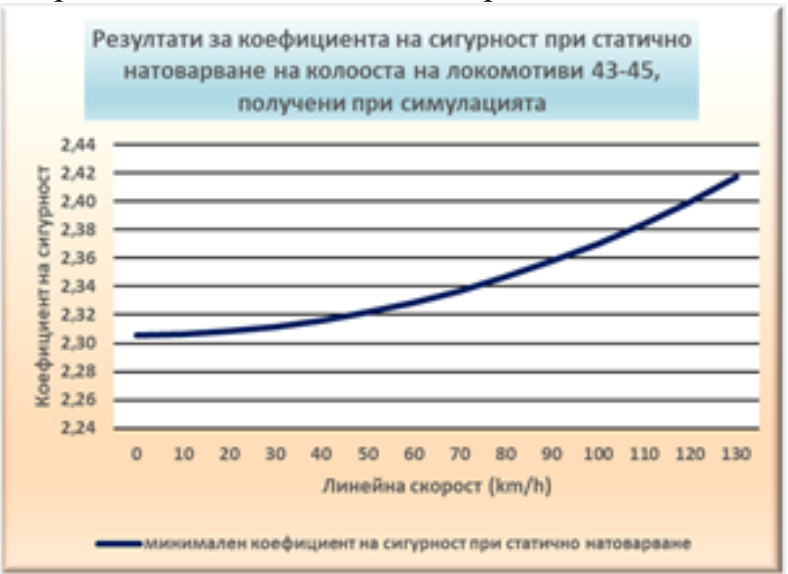

Figure 11

\subsubsection{Fatigue tool safety factor}

The change in the fatigue safety factor is illustrated in fig. 12. Its value increases at different loads in the whole speed range by $4.61 \%$, as the minimum is 0.795 
when starting, and the maximum - when driving at maximum speed -0.833 .

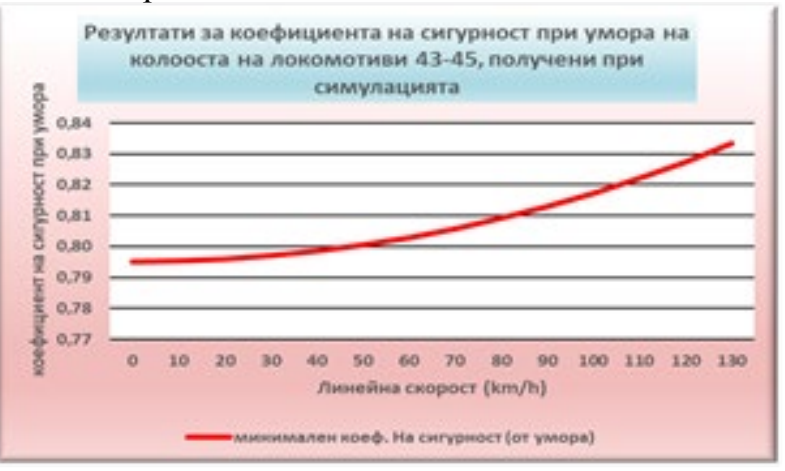

Figure 12

\subsubsection{Fatigue tool, Life}

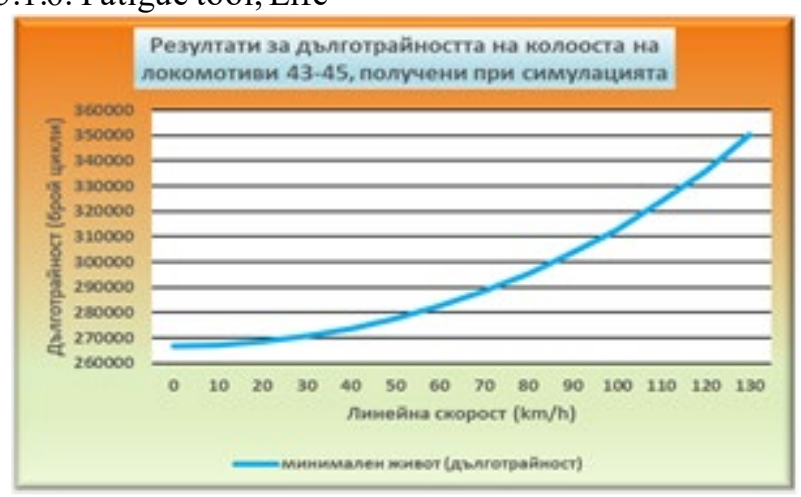

Figure 13

The change in the longevity indicator of the wheel is illustrated in fig. 13. This indicator varies in the range from 266890 cycles when starting to 350130 when driving at maximum speed, i.e., it increased by $23.77 \%$. The maximum is at the weakest point of the wheel - the holker between the two subheadings - the wheel and the gear.

\subsection{Wheelsets of locomotives 46}

\subsubsection{Equivalent stress acting on the wheelset.}

In fig. 14 shows the results obtained during the simulation for the equivalent stress acting in the axle of locomotives 46, and two graphs are formed: for the maximum effective stress obtained in the holker (the transition between the head parts of the wheel and the gear - Fig. 15) and the average for the axle stress over the entire speed range. The maximum stress takes values from $239.22 \mathrm{MPa}$ at start-up to $238.16 \mathrm{MPa}$ at maximum speed and decreases by $0.45 \%$. The tendency of the values of the maximum stress is towards continuous decrease. At the average value of the stress acting on the rim, the maximum value initially assumes a value of $4.00 \mathrm{MPa}$, where with increasing speed there is a slight tendency to decrease to $30 \mathrm{~km} / \mathrm{h}$. This trend is slightly intensifying, and the minimum value of the average equivalent stress is reached at $50 \mathrm{~km} / \mathrm{h}-3.76 \mathrm{MPa}$, increase and the highest $\mathrm{v}$ maximum speed - $130 \mathrm{k}$ stress between 0 and 31 $1.88 \%$, and from 50 to 13

,

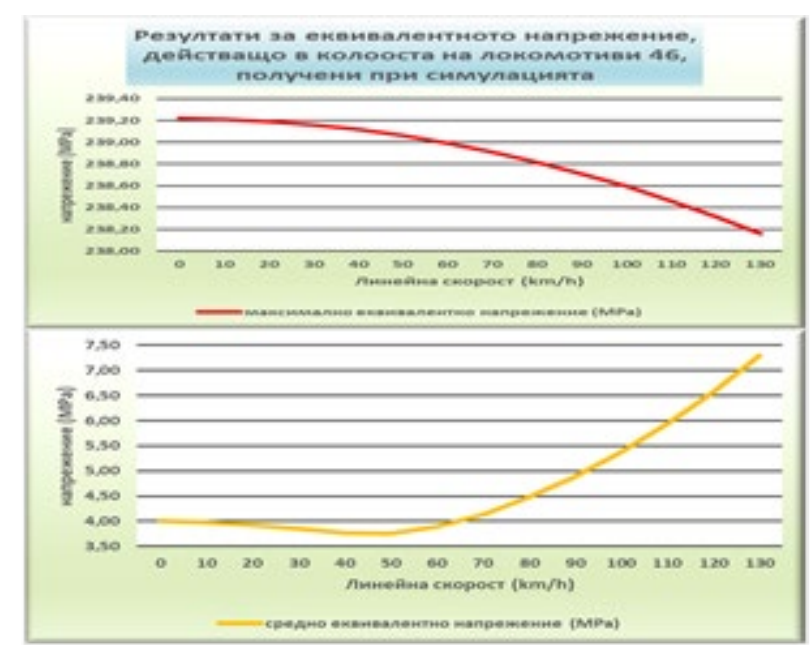

Figure 14

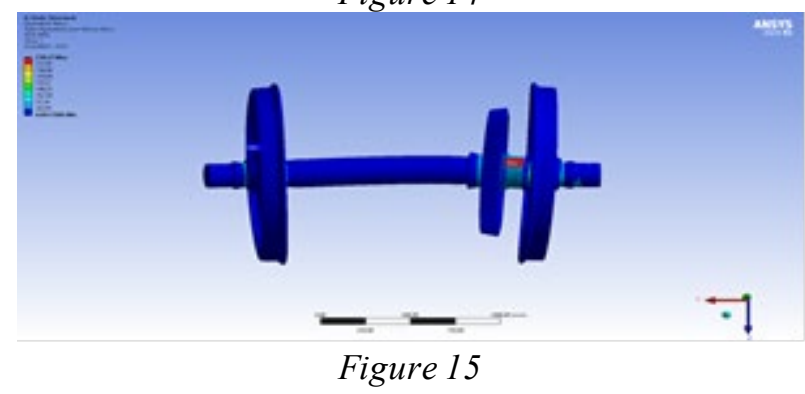

\subsubsection{Equivalent elastic strain}

The values of the equivalent elastic strain of the wheel are shown in fig. 16. The maximum value of the equivalent elastic elongation of the wheel is observed in the holker and decreases with increasing speed, the decrease is $0.48 \%$.

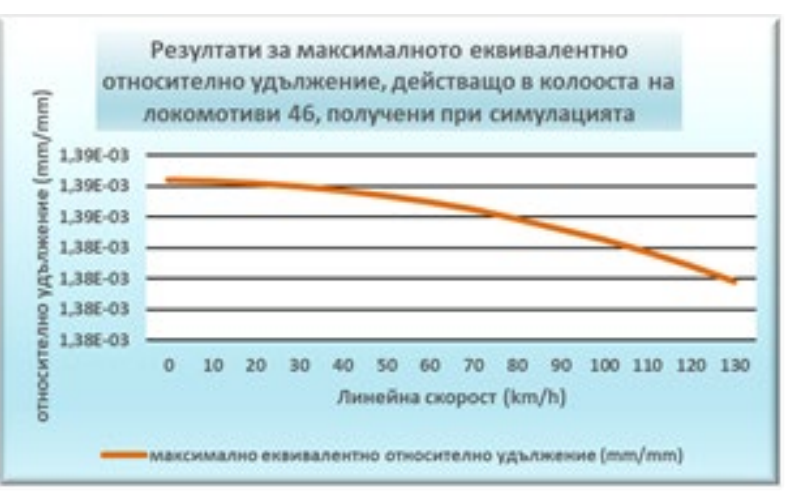

Figure 16

\subsubsection{Total deformation}

The total deformation of the wheelset under load in operating conditions from rest to movement at the maximum allowable speed for the locomotive (Fig. 17). The change in deformation along the wheel under different operating conditions increases from $0.135 \mathrm{~mm}$ when starting to $0.167 \mathrm{~mm}$ at a maximum speed in the range of $19.03 \%$.

\section{Резултати за дълготрайността на колооста на локомотиви 43-45, получени при симулацията}

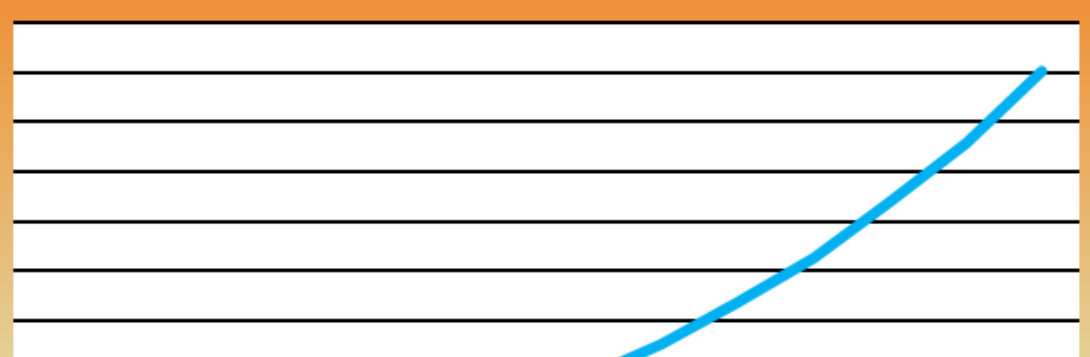




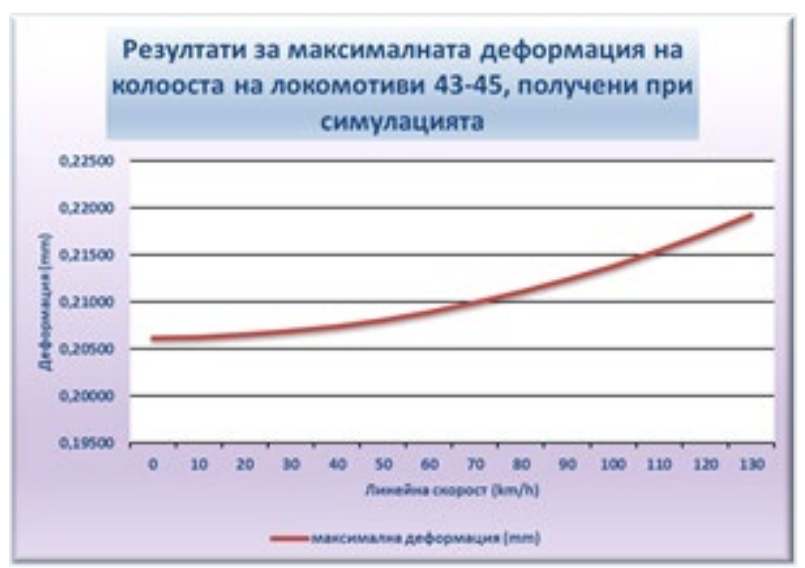

Figure 17

\subsubsection{Safety factor under static load}

The change of this indicator for the wheel ax les of locomotives 46 is illustrated in fig. 18. The trend is towards continuous growth. Its values increase slightly from 1.045 at the time of departure to 1.049 at maximum speed, i.e., with $0.44 \%$.

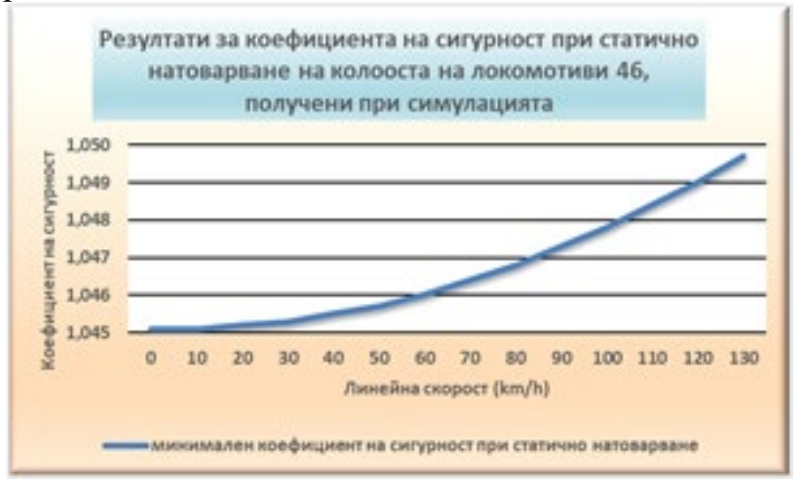

Figure 18

\subsubsection{Fatigue tool safety factor}

The change in the fatigue safety factor in the ax les of locomotives 46 is illustrated in fig. 19. Its value increases at different loads in the whole speed range by $0.44 \%$, as the minimum is 0.3603 when starting, and the maximum - when driving at maximum speed -0.3619 .

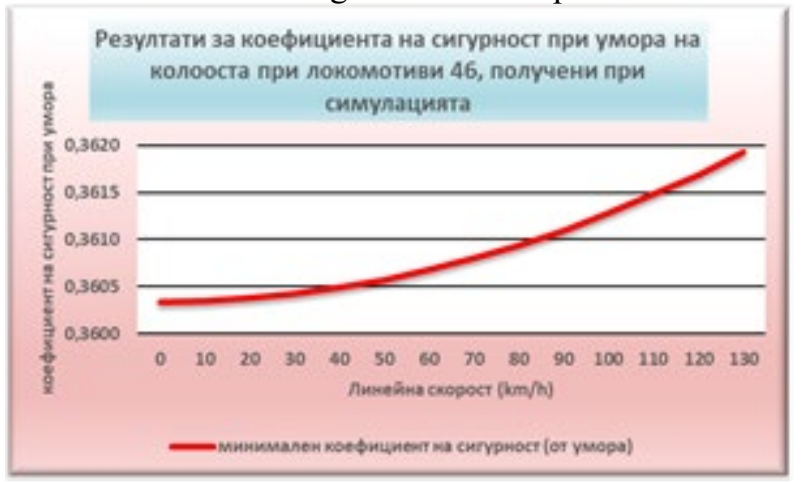

Figure 19

\subsubsection{Fatigue tool, Life}

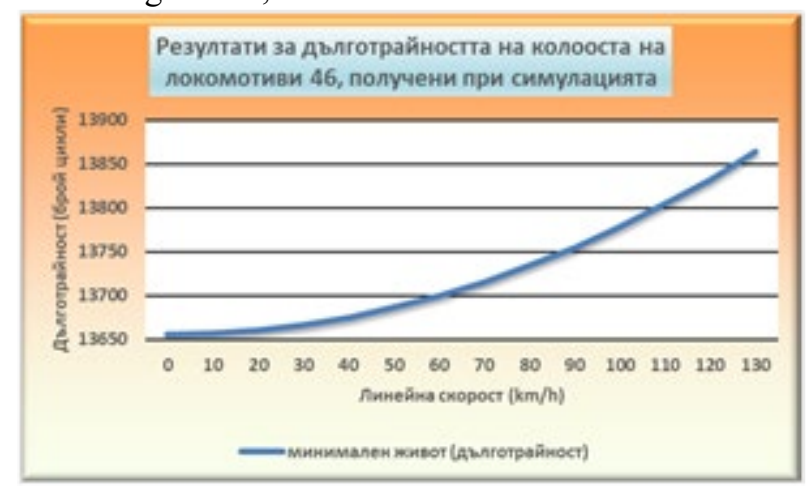

Figure 20

The change in the durability index for the axles of locomotives 46 is illustrated in fig. 20. This indicator varies in the range from 13655 cycles when starting to 13864 cycles when driving at maximum speed, ie. it increases by only $1.51 \%$.

\subsection{Wheelsets of locomotives 86}

\subsubsection{Equivalent stress acting on the wheelset.}

In fig. 21 shows the results obtained during the simulation for the equivalent stress acting in the axle of locomotives 86, and two graphs are formed: for the maximum effective stress obtained in the transition between the pre-head and sub-head part of the axle at the wheel-clamping point and for the mean for the axle stress in the whole range of speeds. The maximum stress takes values from 969,790 $\mathrm{MPa}$ at start-up to $969,470 \mathrm{MPa}$ at maximum speed and decreases by $0.03 \%$. The tendency of the values of the maximum stress is to wards continuous decrease. At the average value of the stress acting on the wheel, the maximum value initially assumes a value of $11,883 \mathrm{MPa}$, with an increase in speed there is a slight tendency to decrease to $80 \mathrm{~km} / \mathrm{h}$. This is the minimum value of the average stress, after which the values begin to increase and the highest value of 14,293 MPa it reaches at a maximum speed $-170 \mathrm{~km} / \mathrm{h}$. The average equivalent stress between 0 and $80 \mathrm{~km} / \mathrm{h}$ tends to decrease by $0.79 \%$, and from 80 to $170 \mathrm{~km} / \mathrm{h}$ increases by $17.03 \%$.

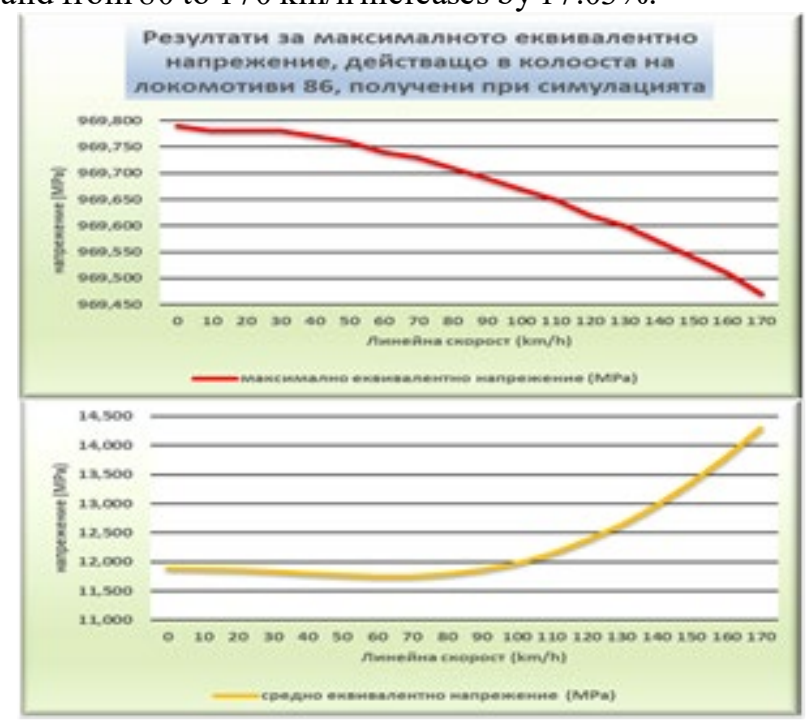

Figure 21 


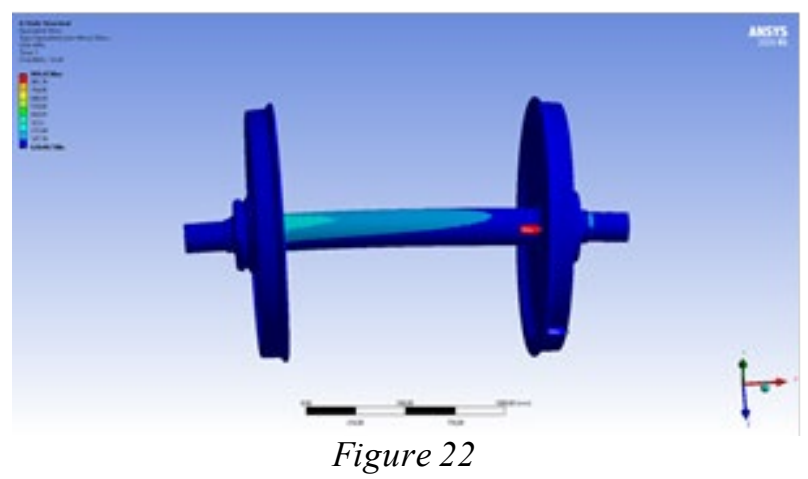

\subsubsection{Equivalent elastic strain}

The values of the equivalent elastic strain of the wheel are shown in fig. 23. The maximum value of the equivalent elastic elongation of the axle is observed in the transition between the pre-head and sub-head part of the axis and decreases with increasing speed of movement, as the decrease is by $0.48 \%$.

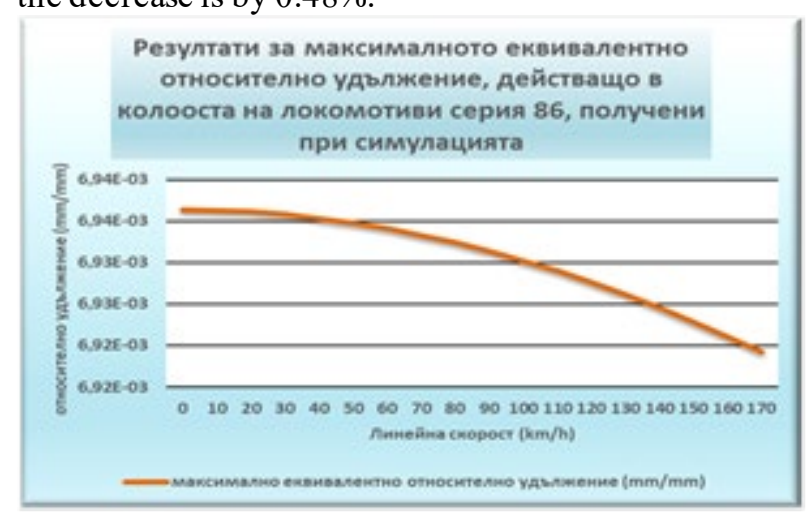

Figure 23

\subsubsection{Total deformation}

The total deformation of the rim illustrates its deformation under load in operating conditions from rest to movement at the maximum allowable speed for the locomotive (Fig. 24). The change in deformation along the wheel itself for the entire speed range remains constant.

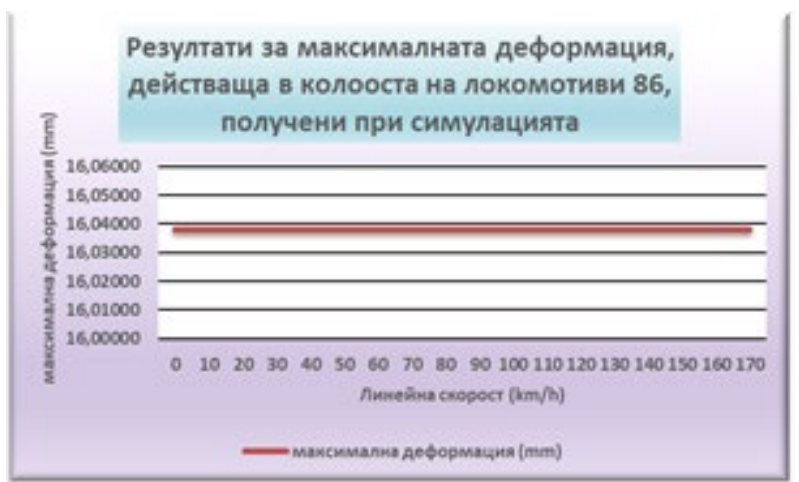

Figure 24

\subsubsection{Safety factor under static load}

The change of this indicator for the wheel axles of locomotives 86 is illustrated in fig. 25. The trend is towards continuous growth. Its values increase slightly from 0.25779 at the time of departure to 0.25787 at maximum speed, i.e., with $0.03 \%$.

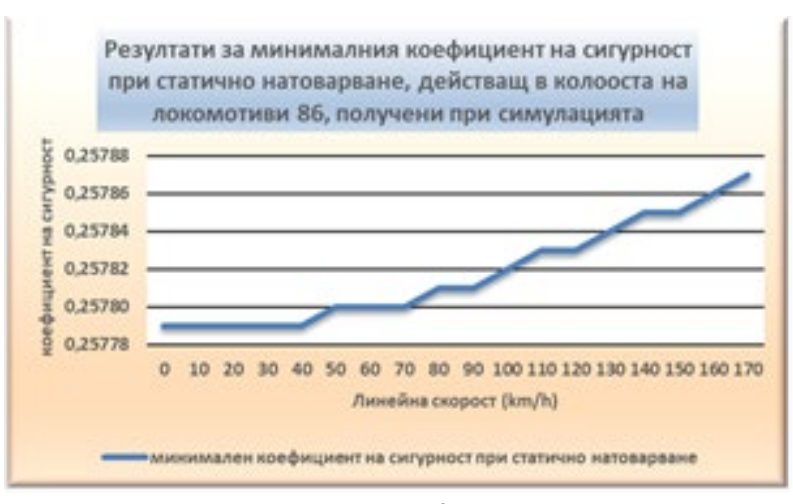

Figure 25

\subsubsection{Fatigue tool safety factor}

The change in the fatigue safety factor in the locomotives of locomotives 86 is illustrated in fig. 26. Its value increases at different loads in the whole speed range by $0.03 \%$, as the minimum is 0,08889 when starting, and the maximum - when driving at maximum speed 0,08891 .

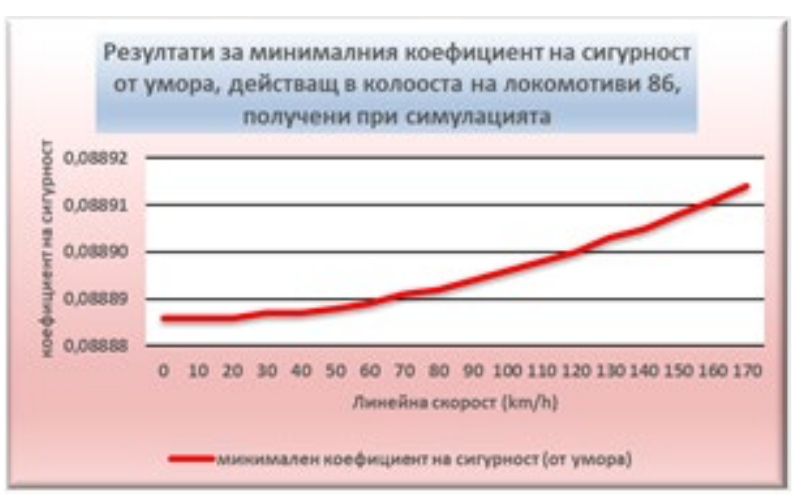

Figure 26

\subsubsection{Fatigue tool, Life}

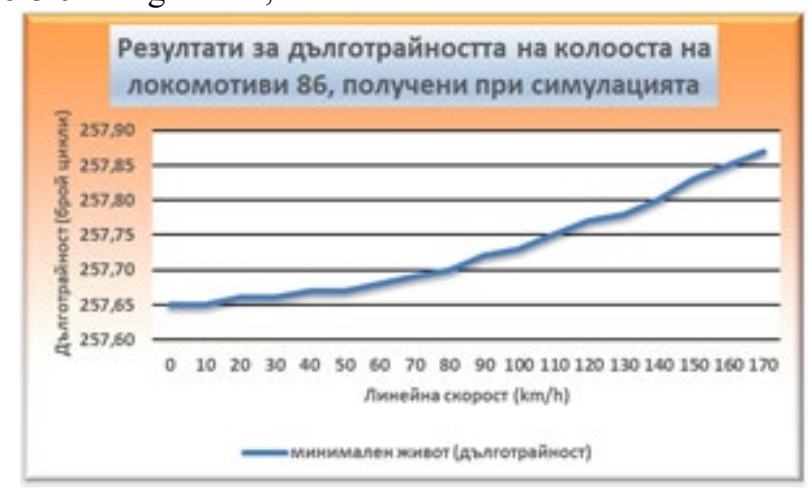

Figure 27

The change in the durability index for the axles of locomotives 46 is illustrated in fig. 27. This indicator varies in the range from 3881200 cycles when starting to 3877900 cycles when driving at maximum speed, ie. it decreased by $0.08 \%$. The minimum value is marked in the transition between the pre-head and sub-head parts of the axle on the side of the wheel, which is not connected to the driving hollow axle.

\section{ANALYSIS OF THE OBTAINED RESULTS}

From the obtained results it can be concluded that the strength characteristics of the axles of the considered 
locomotives in most cases show dependence on both the change of the torque and the change of the speed of the locomotive. This dependence is dominated by two factors to varying degrees: at low speeds torque dominates due to the nature of the traction characteristics of locomotives, then the main factor is the speed due to its increased values on the one hand and on the other due to reduced values of torque, again due to the nature of the traction characteristics of the locomotives.

Another characteristic feature of the change in the strength characteristics of the axles is that no characteristic bend is observed in their graphs when the design speed of the locomotives is exceeded, regardless of the type of their transmission mechanism. This, in turn, once again proves the influence of the speed of the locomotive, respectively the speed of rotation of the axle.

The maximum equivalent stress obtained in the heaviest loaded sections of the wheelsets of all three locomotives shows a tendency to decrease with increasing speed. The decrease is most noticeable for locomotives $43-$ $45-4.83 \%$, for locomotives $46-0.45 \%$ and most imperceptible for locomotives $86-0.03 \%$. This shows that the places where the highest values of stresses are obtained remain potentially dangerous throughout the entire wheelset load range, respectively over the entire speed range of the locomotive. On the other hand, the almost constant high stress obtained in the most endangered sections of the axles gives sufficient reason for designers to think of new ways and methods to strengthen these potentially most dangerous in terms of strength, with out applying the same methods to others. sections where the loads are not so high.

An interesting picture is presented by the graphs of change of the average equivalent stress acting on the axles, which show a change of its values in both directions: to increase and to decrease, depending on the change of torque and speed of movement. In the three cases there is an initial retention of the values around the initial one obtained when starting the locomotive, followed by a decrease in the range from $1 / 2$ to $1 / 3$ of the maximum speed, after which the stress increases rapidly and reaches a maximum value between 1.2 and 1.8 times -higher than when starting, obtained at maximum speed of the locomotive. This shows that at the values of the average equivalent stress acting on the axles, the speed of movement has a greater influence than the torque applied to them.

The maximum equivalent relative strain of the axles shows a steady downward trend with increasing speed, which is a clear sign of the predominant influence of speed before torque on the condition of the axles. The largest difference in the values of this indicator is observed for locomotives $43-45-4.82 \%$, while for the other two types of locomotives it is $1.48 \%$ (for locomotives 46 ) and $0,23 \%$ (for locomotives 86 ). This can be explained both by the structural features of the axle and, in particular, by the choice of material for its manufacture, which for the se locomotives is high-carbon steel with greater elasticity.

The total axle deformation in locomotives 43-45 and 46 also shows a tendency to increase the values with increasing speed, as for locomotives $43-45$ it is $5.95 \%$, and for locomotives $46-19.03 \%$. The latter can be explained by the particularly high values of traction force, respectively torque, at the maximum speed of the locomotive $(9.79 \mathrm{kNm}$ for locomotives 46 at $6.18 \mathrm{kNm}$ for locomotives $43-45$ and $6.98 \mathrm{kNm}$ for locomotives 86 ). Unlike the other two types of locomotives, in locomotives 86 there is a complete invariability of the results of the total deformation - it remains the same for the entire speed range of the locomotive. This proves the advantages of this type of transmission mechanism, which subjects the axle to the same operating conditions during operation, regardless of its operating modes.

Safety factors are parameters that show the reserve of axle strength, providing them with the ability to withstand loads greater than the nominal in different operating modes. The general trend observed is that both the static load safety factor and the fatigue safety factor have the lowest values when starting - a fact that proves once again that at the time of start and at low speed and high torques the reserve of axle strength is the smallest. As the speed increases, both coefficients increase their values (respectively $4.6 \%$ and $4.61 \%$ for locomotives $43-45$, $0.44 \%$ for both coefficients for locomotives 46 and $0.03 \%$ for both coefficients for locomotives 86), as in locomotives 43-45 and 46 this happens smoothly for both coefficients, and in locomotives 86 the increase is stepped, as this is more pronounced for the coefficient of safety under static load and not so much at the safety factor against fatigue. The analysis of the results for the safety factors proves the connection between the values of the maximum equivalent voltage acting in the axis and those of the safety factors, as well as the fact that when designing a locomotive axle special attention should be paid to the sections in which receive the highest stres ses because they determine the values of the safety factors. Another characteristic feature is that the nature of the change in the safety factors does not depend on the type of transmission mechanism - in the three types of locomotives considered there is a clear trend towards increasing the safety factors when increasing the speed, i.e., on the values of these parameters the torque before the speed prevails, regardless of the way of transmitting the traction force to the axle itself.

Despite the same tendency of change of safety coefficients, it should be noted that for locomotives $43-45$ the difference between the minimum and maximum values of their values is many times greater as a function of speed $(4.6 \%$ and $4.61 \%)$, while for the other two types of locomotives the differences are less than $1 \%$ - especially pronounced for locomotives 86 . From the point of view of the loads received in the axles, it can be said that for locomotives 46 and 86 they are constructed more correctly, but from the results obtained in operation, it can be seen that the cases of fractures and cracks in the dangerous sections of the axles are the rarest in locomotives 43-45, from which the following conclusions can be drawn: the axle strength of locomotives 46 and 86 are designed to be in a hazardous area over the entire load range; locomotives 46 and 86 are operated with loads that do not correspond to the strength qualities of their axles; the axles of locomotives 43-45 are designed so that the stresses obtained in the dangerous sections are far from the maximum allowable for the respective material.

The parameter axle life shows the minimum resource that the locomotive axles have and is indicative 
based on the results obtained for the other studied parameters. To a large extent, its values overlap as a trend with the values for the safety factors and confirm the obtained results.

\section{CONCLUSIONS AND RECOMMENDATIONS}

The conducted research and the made analys es of the obtained results give grounds to make the following conclusions:

- The load of the locomotive axles is not constant in the different modes of operation of the locomotives and is constantly changing in operation;

- The load on the locomotive axles during operation depends on both the torque applied to them by the traction motor and the instantaneous speed of the locomotive;

- Different axle strengths are affected to varying degrees by applied loads: some of them depend more on the applied torque, others are more affected by the instantaneous speed;

- The type of transmission used in the different locomotives has a significant effect on the values of individual indicators and must always be taken into account when designing locomotive axles.

Locomotive axles, as one of the main elements of the running gear and the propulsion of locomotives, on which the safety of traffic in railway transport directly depends, are constantly in the focus of researchers and designers in this field. In their design and construction must be taken into account not only all the parameters that affect their strength and durability, but also their change in all modes to which they will be subjected in operation.

\section{REFERENCES}

[1] Atmadzhova D., Mihaylov E., Iontchev E., ,Study of the interaction "wheelset-track" of the attacking wheelset of tram bogie type T81 in exploitation in Sofia”, IX International Scientific Conference Heavy Machinery НМ 2017, Златибор, Сърбия, 2017 г. pp. E33-E40, 2017r.

[2] EN 13261:2009 UIC Code 515-3. Rolling stock. Bogies - Running gear. Axle design calculation method. 2009.
[3] Николов, В. Изследване на факторите, влияещи на дълготрайността на локомотивните колооси, С. ТУ, 2008.

[4] Николов, В., Влияние на спирачните усилия върху якостните качества на локомотивните оси, Научна конференция с международно участие по авиационна, автомобилна и железопьтна техника и технологии, Созопол, 2009.

[5] Николов, В., Тяга на влаковете - ръководство за упражнения и курсово проектиране, С., ВТУ, 2012.

[6] Ружеков, Т., Ж. Димитров, Д. Стоянов, Г. Стайков, А. Стефанов. Конструкция, теория и проектиране на локомотиви. С., ТУ - София, 1987.

\section{Uticaj vučne sile i brzine kretanja na čvrstoću osovina lokomotive}

\author{
Vasko Nikolov ${ }^{1 *}$ \\ ${ }^{1}$ Katedra za transportnu opremu, Transportni univerzitet \\ Todor Kableškov, Sofija, Bugarska \\ U članku su prikazane zavisnosti dobijene pri \\ istraživanju opterećenja na osovinama lokomotive $u$ \\ zavisnosti od vučne sile $i$ brzine kretanja lokomotive. \\ Vučna karakteristika lokomotive je odnos između vučne \\ sile koju postižu vučni motori i brzine kretanja, a ona je \\ različita u različitim uslovima vožnje. Razmatraju se \\ različiti načini rada osovina lokomotiva. Razvijena je \\ simulacija ponašanja osovina. Izračunate su karakteristike \\ čvrstoće i deformacije osovina lokomotive pri različitim \\ režimima opterećenja. Urađena je uporedna analiza \\ čvrstoće lokomotiva sa različitim klasama prenosnih \\ mehanizama.
}

Ključne reči: Osovine lokomotiva, Karakteristika čvrstoće, Uporedna analiza, Vučna karakteristika, analiza čvrstoće, Simulacija, Vučna sila 